\title{
Un médico en la Guerra Civil española: el doctor Pablo Uriel Díez
}

\author{
José María Izquierdo \\ Universidad de Oslo
}

\begin{abstract}
Resumen:
En la fase actual de recuperación de la memoria histórica de la Guerra Civil española ha surgido con fuerza el cómic relacionado con este tema tanto en forma de tiras o historietas como en el género de la llamada novela gráfica. En el caso de la trilogía de Sento, es decir Un médico novato (2013), Atrapado en Belchite (2015) y Vencedor y Vencido (2016), se elabora la biografía de un médico no perteneciente ideológicamente al bando nacional que por circunstancias de los acontecimientos históricos tiene que ejercer la medicina en el frente del bando mencionado. La trilogía está basada en una documentación que se incluye parcialmente en los anexos de las novelas mencionadas. En ese sentido cabe la posibilidad de clasificar los textos de Sento como obras gráficas que son ejemplos de la ya amplia literatura de la llamada posmemoria.
\end{abstract}

Palabras clave: memoria, posmemoria, Guerra Civil española, novela gráfica

\begin{abstract}
:
In the ongoing recovery of the historical memory of the Spanish Civil War, comics addressing the topic have emerged with force, both in the form of comic strips and short stories, and within the genre of the graphic novel. Sento's trilogy, including Un médico novato (2013), Atrapado en Belchite (2015) and Vencedor y vencido (2016), is a biography of a doctor who, as a consequence of the circumstances of the historical events, has to work at the front of the national bloc despite not belonging to it ideologically. The trilogy is based on documentation which is partially included in the annexes of the novels, and in the testimony of doctor Pablo Uriel. As such, it is possible to categorize Sento's texts as graphic novels of postmemory.
\end{abstract}

Keywords: memory, postmemory, Spanish Civil War, graphic novel

\section{Introducción: "Parar las olas del olvido"}

El asunto del olvido, inducido o no, y de la memoria individual, colectiva, de la denominada posmemoria (Hirsch) o en otras palabras "escribir de oídas" (Izquierdo, "Maquis" y "Escribir de oídas"), (pos-) memoria afiliativa (Faber) o relacionadas con la historiografía, verdad histórica o documental, ha sido recurrente en la literatura española. El mencionado tema de la memoria en sus diferentes variantes ha sido tratado en numerosas novelas clasificadas temáticamente como de la Guerra Civil española y su posguerra. La memoria novelada de la Guerra Civil no ha sido la única existente frente al llamado pacto del olvido/silencio vinculado a la promulgación de la Ley de la amnistía promulgada en la España de 1977. La Ley 46/1977 que, recordemos, dice en su capítulo segundo apartados e-f: 
En todo caso están comprendidos en la amnistía: [...] e) Los delitos y faltas que pudieran haber cometido las autoridades, funcionarios y agentes del orden público, con motivo u ocasión de la investigación y persecución de los actos incluidos en esta ley. f) Los delitos cometidos por los funcionarios y agentes del orden público contra el ejercicio de los derechos de las personas. (Iberley)

Las artes gráficas y, en concreto el cómic, van a jugar también un papel muy importante en la recuperación de la memoria histórica (Izquierdo "La guerra Civil española como tema”, 8-17) y de la restitución de las víctimas del bando derrotado en la Guerra Civil. En este caso me propongo comentar un conjunto de textos relacionados entre sí y que son el testimonio directo del doctor en medicina Pablo Uriel (1914-1990) o que están basados en la memoria de las vivencias del mismo:

- Mi guerra civil $(1964,1975,1988)$ de Pablo Uriel Díez

- No se fusila en domingo (2005) de Pablo Uriel Díez

- Un médico novato (2013-2014) de Vicent Josep ‘Sento' Llobell Bisbal

- Atrapado en Belchite (2015-2016) de Vicent Josep 'Sento' Llobell Bisbal

- Vencedor y vencido (2016-2017) Vicent Josep 'Sento' Llobell Bisbal

- Dr. Uriel (2017), recopilación de la trilogía anteriormente mencionada, de Vicent Josep ‘Sento' Llobell Bisbal

El ciclo del Dr. Uriel se completa con su divulgación en forma de explotaciones didácticas a través del sitio de internet elaborado por el dibujante y guionista Llobell Bisbal bajo el título de "El Dr. Uriel en las aulas" (2014).

\section{No se fusila en domingo}

La mencionada Mi guerra civil es una típica novela testimonial, de hecho, su existencia se basa en la necesidad del autor de contrarrestar las celebraciones del vigesimoquinto aniversario del fin de la Guerra Civil que el régimen franquista celebró bajo el eslogan 'Veinticinco años de paz', el 1 de abril de 1964.

Mis hijos eran los destinatarios preferidos de esta campaña que les llegaba a través de sus clases en el instituto, [...] Nadie podía explicar a la juventud española que esa paz era la consecuencia del miedo residual, la secuela de un terror sistemático. Me propuse contrarrestar esa campaña contándoles cómo vivió su padre la guerra civil. Los hechos estaban aún frescos en mi memoria, y me ayudé de las notas que había tomado durante la contienda. (Uriel, No se fusila 17)

De esta forma Uriel reúne el tema del olvido cervantino "parar las aguas del olvido" (Cervantes 1186) con el del cronista autorial testimonial montalbaniano de Elpianista (1985) "Saber expresarse, saber poner por escrito lo que uno piensa y siente es como poder enviar mensajes de náufrago dentro de una botella a la posteridad" (Vázquez Montalbán 138-139), que ya mencioné en otro artículo (Izquierdo, "La guerra civil española como tema" 1-2), escribiendo una novela que informa a sus hijos de lo que no se informaba durante la postguerra por el franquismo cuando ellos eran niños, pero que también será un mensaje de náufrago para la posteridad. 
Ese texto de 1964 será, varios años después, el desencadenante de los álbumes mencionados anteriormente, de su recopilación posterior, de varias exposiciones y de diversas explotaciones didácticas.

La edición de 2005 realizada por la hija del autor, Elena Uriel, se inicia con una cita de André Malraux, un prólogo de Ian Gibson, una nota explicativa del autor a la edición de 1975 y otra nota explicativa de la edición de 2005 escrita por la editora. Además, e iniciando un modelo que se reproducirá en la trilogía de las novelas gráficas del Doctor Uriel, incluye también un epílogo a cargo de Elena Uriel con notas bibliográficas de algunos protagonistas del testimonio, un apéndice con diversos documentos y sus transcripciones y, finalmente, una colección de fotografías relacionadas con el doctor, y algunos documentos y objetos relevantes en la elaboración del relato.

La novela se divide en tres partes de distinta extensión: "La represión" y "En el ejército de Franco", de tamaño similar, y otra mucho más corta bajo el título "En la zona republicana". Estos a modo de capítulos estructuran el relato del narrador protagonista que, a lo largo de la Guerra Civil, tuvo que interpretar los papeles de estudiante de medicina recién salido de la facultad, de médico rural en su primer destino — en la Rioja- en prácticas en 1936, de preso político en el bando nacional en la Zaragoza nacional, de médico militar en el frente de Aragón, en concreto en Belchite - para escapar de la represión franquista que le había apresado en Zaragoza y que fusiló a su hermano Antonio. Y, por último, el de preso en una cárcel republicana en Valencia.

No se fusila en domingo es una novela de la memoria individual, testimonial de Uriel, editada de forma cooperativa, familiar, tal y como describen Elena Uriel, la hija del doctor, y el doctor mismo.

Hacia 1975, y como regalo de cumpleaños, editamos un único ejemplar de su libro mecanografiado, ilustrado, prologado y encuadernado por familiares y amigos. [...] En 1988 nos atrevimos a más y, dirigidos por mi madre, hicimos una edición familiar de unos mil ejemplares que titulamos "Mi guerra civil". Fue prologada por Ian Gibson... (Uriel, No se fusila 21-22)

El texto, por razones obvias, no podía ser editado en aquellos momentos (1964). Ahora, mi familia ha conspirado para lograr su difusión y me ha ofrecido como regalo el prólogo de Ian Gibson, que yo no me hubiera atrevido a pretender. Mis hijos Patricia y Pablo han colaborado con la aportación fotográfica, composición y corrección. Mi hija Elena aportó su sensibilidad artística ilustrando algunos pasajes del libro. (Uriel, No se fusila 18)

Uriel se presenta en el libro como miembro de la dirección de la Federación Universitaria Escolar (Uriel, No se fusila 122) en la Universidad de Zaragoza, organización fundada en 1926 y que protagonizó diversas luchas contra la dictadura de Primo de Rivera y la monarquía. Esta federación de vago republicanismo se disolvió con la proclamación de la Segunda República Española. En otro momento de la novela se nos menciona su vinculación a un proyecto político — en la propia FUE - más definido: el Grupo Izquierdista Universitario (Uriel, No se fusila 178). En todo momento el lector comprende la difusa politización del doctor; si algo caracteriza a Uriel es su posición democrática, humanista y liberal con una sensibilidad clara hacia la justicia social. A lo largo de su relato testimonial resaltan algunos temas tales como el de la 'banalidad del 
mal' (Arendt 1963) que relacionamos con la burocratización de la represión, ${ }^{1}$ la frialdad del victimario en el sistemático aniquilamiento del enemigo y a su vez la perpleja pasividad de las víctimas, su trauma.

En uno de los chalets del paseo de Ruiseñores de Zaragoza, estaba instalada la oficina de una sección del SIM (Servicio de Información Militar). Aunque nosotros no lo sabíamos entonces, allí se encontraba el hombre todopoderoso que manejaba nuestras vidas. Estudiaba nuestras circunstancias personales, pedía, a veces informes a la universidad, a la policía o a la Iglesia, y tomaba sobre nuestros destinos cualquiera de estas dos decisiones: muerte o libertad. No había sanciones intermedias. (Uriel, No se fusila 133)

El enlace ciclista llevaba esta orden a la jefatura de Falange, y esta autoridad se presentaba en la prisión militar y canjeaba la orden por el detenido. Diez o quince minutos más tarde, la sentencia se había cumplido. "Si no está reclamado por otra autoridad." Siete palabras inocentes que costaban la vida de un hombre. Todo era muy limpio, muy aséptico, muy silencioso. La palabra "muerte" no se había pronunciado ni figuraba en ningún texto. (Uriel, No se fusila 134)

La gente mataba con facilidad, y moría también con facilidad. La docilidad para morir sin resistencia no era simple cobardía. Esos hombres eran de la misma clase que los que luchaban con heroísmo en los frentes. Pero cuando iban a la muerte en un camión, mezclados con sus asesinos, había quizás en cada uno de ellos la convicción de que aquello no podía sucederles a ellos, que ocurriría algo que impediría una muerte tan estúpida. Y morían sumergidos en una especie de pasmada perplejidad que anulaba su capacidad de lucha. Algo así sentiría yo, más adelante, al verme en el lugar de las víctimas. (Uriel, No se fusila 44)

Todos los vencedores colaboraron con los verdugos falangistas con su conformidad. [...] Los hombres que no ejecutaban denunciaban, y, al enterarse de que el denunciado había sido paseado, imaginaban enseguida que su denuncia habría servido para descubrir en la víctima otros horrendos delitos. Aquel denunciado había resultado ser un rojo perdido, y la hora de la justicia había sonado en España. (Uriel, No se fusila 65)

En la novela del doctor Uriel se describe también —a través de diferentes ejemplosel tema de la legitimidad de la representación política en plena guerra civil tanto en el bando nacional como en el republicano, en ambos divididos en diversas corrientes ideológicas, organizaciones y sensibilidades. En el testimonio del doctor leemos también varios episodios de confraternización entre los combatientes de ambos bandos en forma de reparto de periódicos, intercambio de avisos, de tabaco y papel de fumar, etc... Confraternización que nos hace recordar la película La vaquilla (1985) de Luis García Berlanga (1921-2010) que muestra una hipotética diferenciación entre la población y sus direcciones políticas.

El miliciano y el soldado franquista eran dos soldados españoles dispuestos a convivir sin renunciar a sus diferencias. Eran el pueblo español, obligado a luchar por la intransigencia de unos generales que, para conseguirlo todo, se habían arriesgado a perderlo. (Uriel, No se fusila 283)

\footnotetext{
${ }^{1}$ El mensaje que se emitía liberando al detenido era: "Señor brigada jefe de la prisión de San Gregorio: Sírvase poner en libertad al soldado recluso Fulano de Tal. Dios guarde a usted muchos años. Zaragoza, fecha. Primer año triunfal." (Uriel, No se fusila 133) En el mensaje que daba orden a la ejecución del detenido se incluía una frase condicional: "si no está reclamado por otra autoridad." (Uriel, No se fusila 134)
} 
Otros temas subyacentes serán la tendencia a la fragmentación de las izquierdas españolas, la actitud de los católicos en el bando nacional, la represión en los territorios de ambos bandos — sistemática en el bando nacional y desorganizada en el republicano, la diferente percepción de la misma en ambos bandos, la pervivencia del terror en y tras la guerra, el conflicto de lealtades personalizadas o la existencia de humanidad en individualidades singulares, excepcionales, en tanto la prisión como en el frente del bando nacional.

Otro de los asuntos que sorprende al lector es la dicotomía retaguardia-frente y sus diferentes grados de peligrosidad.

Me había propuesto solicitar un destino en el frente para huir del ambiente opresivo y peligroso de la ciudad, y para situarme en condiciones de evadirme a la otra zona, si tenía el valor de hacerlo. (Uriel, No se fusila 207)

No quería morir y dejar a su hijo en el pueblo, con la amenaza constante de una denuncia o una nueva detención; no había otra manera de lograrlo que enrolándolo como voluntario en las milicias o en el ejército. [...] Era más seguro lanzarlo a la guerra que dejarlo en la paz aparente de la retaguardia. (Uriel, No se fusila 48)

No se fusila en domingo es el testimonio de las vivencias de un médico republicano que, por los avatares de los acontecimientos históricos desencadenados por el golpe militar, tuvo que pasar hasta el mes de septiembre de 1937 en el bando nacional. Es el relato de un médico sin una afiliación determinada, pero muy crítico hacia la deshumanización del terror propiciado por el golpe militar y utilizado sistemáticamente en el bando nacional. Su actitud ética le hace situarse en los límites de las acciones descritas ya sea, fundamentalmente, en el bando nacional o en el republicano, pero sin equidistancias.

\section{El doctor Uriel}

El éxito de la novela gráfica española es evidente. Basta con entrar en una librería para ver su enorme éxito. Los títulos de Paco Roca (1969) y sus Arrugas (2007), El invierno del dibujante (2010) y Los surcos del azar (2013) o de Laura Ballester, Cristina Durán y Miguel Ángel Giner y su El día 3 (2018) que relata el accidente del metro de Valencia (2006) y sus posteriores secuelas jurídicas y políticas. Y dentro de la amplia nómina de cómics y novelas gráficas cuyo tema es la Guerra Civil española destaca Dr. Uriel (2013-2017) de Vicent Josep Llobell Bisbal 'Sento' (1953-). Y destacan, entre otras razones, porque a la filiación genealógica del autor y dibujante establecida con el protagonista real del relato basado en su testimonio documental se une lo que Sebastiaan Faber denominará acto afiliativo relacionado con la posmemoria del autor dibujante como exponente intergeneracional. Acto afiliativo que, y cito a Faber, "en el caso español reside, en gran parte, en la dimensión política de la memoria histórica de la Guerra Civil" (Faber 148). Aquí cabe la pregunta de si esa dimensión política es clara o difusa. En otro texto ya expliqué que durante los años ochenta del siglo pasado muchas de las novelas de la Guerra Civil española no tienen una afiliación política clara, aunque en ellas sí se manifieste una fuerte posición ética (Izquierdo, "Maquis"). 
La actual y definitiva edición del Dr. Uriel (2017) es en realidad la unión de tres álbumes: Un médico novato (2013), Atrapado en Belchite (2015) y Vencedor y vencido (2016). El texto se basa en las memorias del doctor Pablo Uriel, suegro de 'Sento' Llobet escritas en No se fusila en domingo (2008) y en un conjunto de documentos - carnets, fotografías, cartas, textos oficiales, etc.- que encuadran la trama de la narración y que se recogerán en un anexo bajo el título "Álbum de recuerdos". Los tres álbumes que han dado origen al texto se han integrado en la edición actual en forma de tres partes y con ellas se han incluido algunos de los paratextos existentes con anterioridad. El primero de ellos, la dedicatoria, es el que le confiere el carácter de filiación genealógica o familiar:

Este libro está dedicado al doctor Uriel Díez y a todos los profesionales de la sanidad de nuestra familia... (Sento, Dr. Uriel 5)

El segundo será el que le va a conferir el aspecto afiliativo y político, es una cita de L'Espoir (1937) de André Malraux:

Algunas guerras pueden ser justas, pero ningún ejército es inocente (Sento, Dr. Uriel 6)

En el contexto de la novela gráfica de la que escribimos esta cita es una declaración de principios acerca del reconocimiento de que en una situación bélica no hay ejércitos que puedan considerarse como libres de culpa.

El relato se cierra con otro paratexto previo al "Album de recuerdos" en el que se expresa un posicionamiento ético y político frente a lo relatado y al nuevo régimen constituido:

A Pablo Uriel le fue concedida, en febrero de 1941, la medalla de sufrimientos por la patria. Nunca fue a recogerla. (Sento, Dr. Uriel 395)

A lo largo de toda la novela gráfica serán esos tres paratextos los que determinen el porqué de la edición y la posición afiliativa del autor.

La primera parte de la narración, "Un médico novato", se inicia en el verano de 1936 y se nos relatan episodios de la vida del protagonista: el inicio de la guerra, la licenciatura en medicina, su primer trabajo destinado como sustituto del médico rural de un pueblecito riojano, su llamamiento a filas en el ejército nacional y su ingreso en prisión por sus ideas progresistas. Esta primera parte de la novela gráfica se divide en "La piragua", en la que se relatan diversos acontecimientos de la vida de Uriel, y "Radio Celda 14", en la que se describe a Uriel como víctima de la represión iniciada por el golpe militar.

En la segunda parte, “Atrapado en Belchite”, el protagonista es liberado de la cárcel, pero ante la inseguridad que le produce vivir en una ciudad franquista decide pedir, en el verano de 1937, ir al frente siendo destinado al pueblo de Belchite. Si en la primera parte el lector observa y lee el miedo de Pablo, los abusos, la violencia física y psicológica, y la amistad entre los presos como resistencia contra los victimarios, en la segunda el tema será el horror de la guerra, la impotencia, el dolor, la crueldad de los falangistas, pero al mismo tiempo la lucha por la supervivencia y el placer de seguir vivo. 
En la tercera parte, "Vencedor o vencido", tras la caída de Belchite, el protagonista será enviado preso a Valencia, a la prisión del Puig, apareciendo la ambivalencia existente en un protagonista preso por ser oficial médico del ejército nacional, preso en una cárcel de un bando con el que simpatiza ideológicamente por lo que representa de progreso social etc. Al final será "liberado" en marzo de 1939 por los vencedores de la guerra, sintiéndose al mismo tiempo vencido por no ser los "suyos" y por la sensación de pérdida producida por los tres años del horror de la guerra y de la represión política que conllevó.

En las tres partes del libro encontramos ejemplos de la simbiosis entre la narración literaria y la conformada por imágenes que caracteriza a las novelas gráficas. Simbiosis en la que el aspecto gráfico es el preponderante dado que" las viñetas no son ilustraciones de un texto literario, sino que son el texto" (Izquierdo, "Un médico"). En el anexo gráfico de este artículo pueden verse algunos ejemplos de narratología gráfica.

\section{Memoria e Historia}

Uno de los aspectos mejor cuidado del Dr. Uriel y de los álbumes que lo preceden constituye la hibridación de aspectos de la memoria individual/personal del protagonista con la base documental histórica. Lamentablemente solo vamos a poder mencionar un par de ejemplos.

En "Vencedor o vencido" se describe un bombardeo en Valencia de la Aviazione Legionaria que tenía su base aérea en Mallorca. Los aviones utilizados habitualmente eran biplanos Fiat CR-32 o bien bombarderos Savois-Marchetti SM79, al mismo tiempo en 1936 la Luftwaffe bombardeó Bilbao siendo muy célebre la fotografía de Robert Capa en la que se ven a unos bilbaínos observando el cielo, tal y como podemos ver en las figuras 1 y 2 . En las viñetas de abajo vemos cómo los aviones son los ya mencionados modelos, la imagen muestra también una vista aérea de la Valencia de la época con las torres de la iglesia de santa Catalina, el Miguelete y la linterna octogonal de la catedral. En cambio, se utiliza una copia de la célebre fotografía de Capa del bombardeo de Bilbao. La licencia poética del uso de esta fotografía tiene el doble propósito de utilizar un icono reconocible por el lector en el que se muestra a la población, sin distinciones ideológicas, de Bilbao como víctimas. Miran al cielo con una curiosidad e incredulidad que anteceden al terror del bombardeo. 


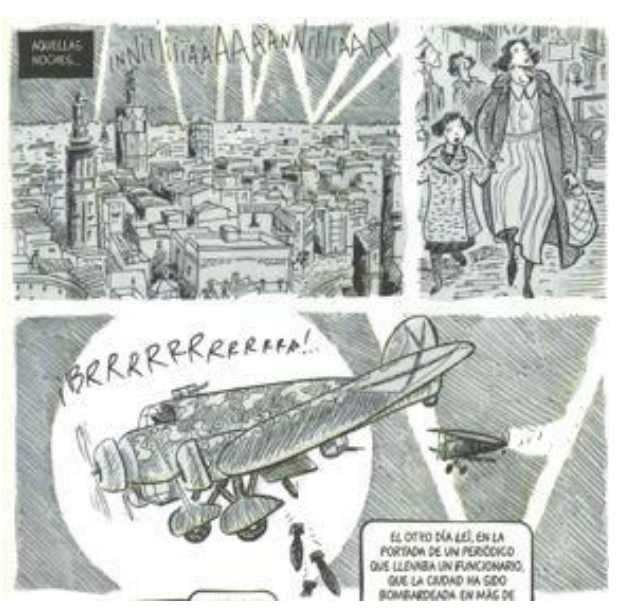

Figura 1: Campaña de bombardeos en el Levante (Sento, Dr. Uriel 325)

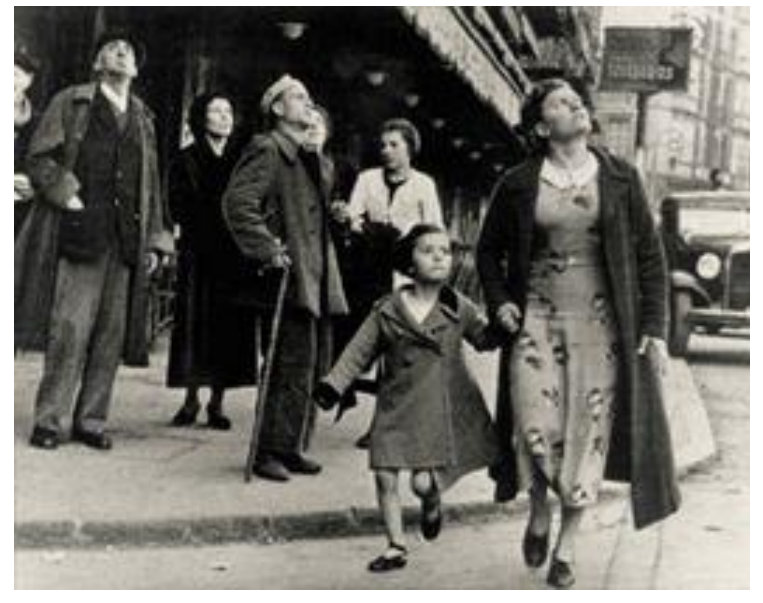

Figura 2: Luftwaffe, Bilbao 1936

La colección de objetos, cartas, documentos etc., que se adjuntan en la trilogía reproducen el trauma de la experiencia vivida. Además, esa colección servirá en las obras gráficas para verificar los episodios relatados. No podemos olvidar que las novelas gráficas son construcciones narrativas donde las tramas son el resultado de la combinación de diferentes niveles de representación textual y su expresión gráfica.

El dato real y la licencia poética confieren un realismo aceptable para el lector en su pacto de lectura del artefacto híbrido formado por el texto escrito y el gráfico. Todo el texto recupera infinidad de imágenes de la época que forman parte de la memoria individual y colectiva de los lectores a los que va dirigida la novela gráfica.

El otro ejemplo está referido al fusilamiento de Antonio Uribe, hermano del doctor, en No se fusila en domingo se dice:

Dieciséis hombres cruzaron la puerta de la cárcel del Burgo (de Osma), esposados y conducidos por guardias civiles, y subieron a la caja de un camión que les esperaba junto a la puerta. Algunos hombres del pueblo contemplaban la escena ya rutinaria para ellos. La nota discordante la daba la negra silueta de un sacerdote que se movía afanoso entre los hombres y los guardias. [...] No los mataron a todos juntos. [...] El sacerdote realizó allí su grotesca parodia, y los cuerpos quedaron bajo los pinos. (Uriel, No se fusila 73-74)

En la novela gráfica se completa el papel del cura en el relato del fusilamiento con la entrega del reloj de Antonio por parte de un número de la Guardia civil al sacerdote con el comentario: "Tenga, padre, la parte para su parroquia" (Sento, Dr. Uriel 62). 

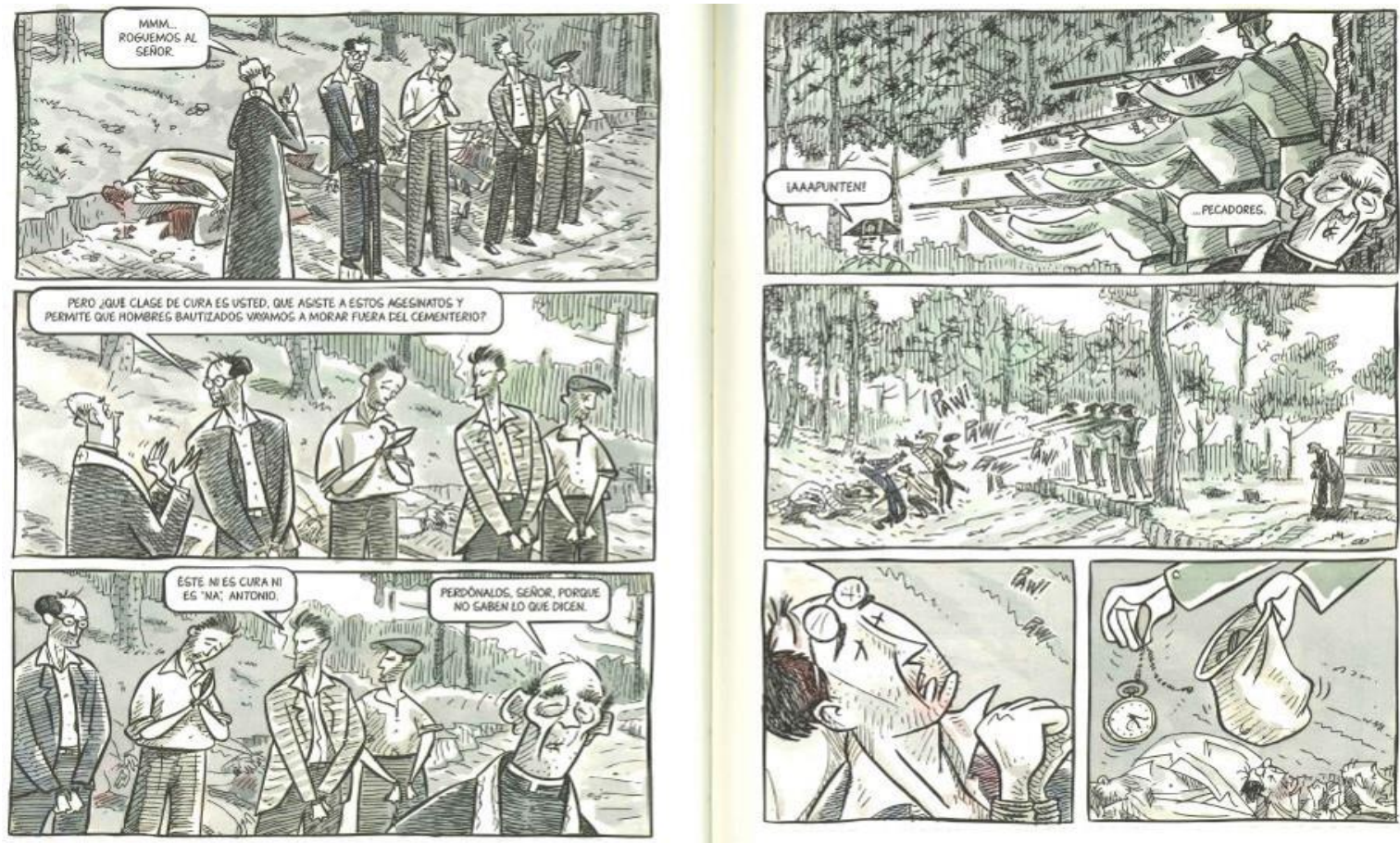

Figura 3: Fusilamiento de Antonio Uriel Díez (Sento, Dr. Uriel 60)

En el anexo aparece la referencia física del reloj de Antonio y una carta —otro ejemplo de la 'banalidad del mal'- que recibió la familia en 1937 explicando el envío:

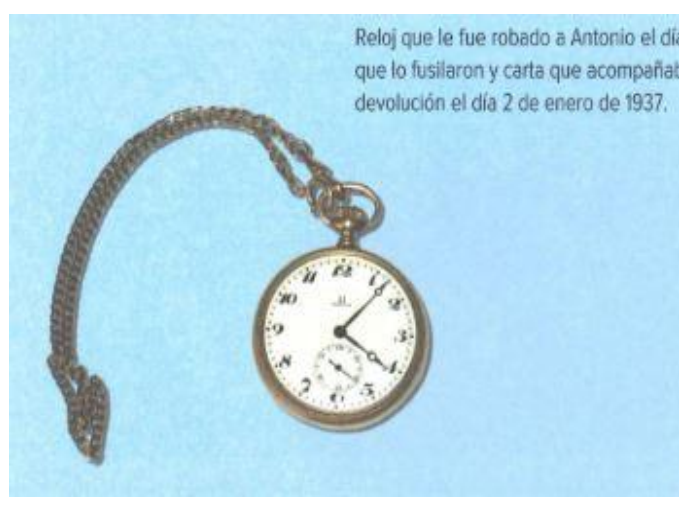

Figura 4: Reloj de Antonio (Sento, Dr. Uriel 400)

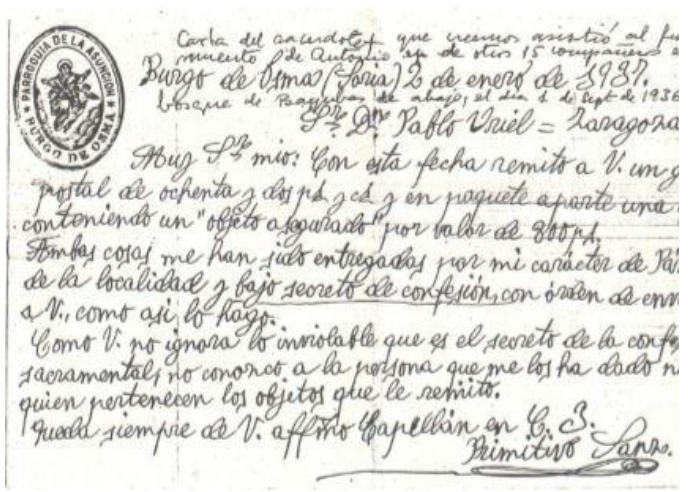

Figura 5: Carta del cura (Sento, Dr. Uriel 400)

Comentario escrito por Cándida sobre la carta:

Carta del sacerdote que creemos asistió al fusilamiento de Antonio y de otros quince compañeros en el bosque de Bayubas de Abajo, el día 1 de septiembre de 1936.

Burgo de Osma (Soria) 2 de enero de 1937. 
Sr. Don Pablo Uriel $=$ Zaragoza $=$

Muy Sr. mío: Con esta fecha remito a V. un giro postal de 82 ptas. y cts. y en un paquete aparte una cajita conteniendo un "objeto asegurado" por valor de 800 ptas. Ambas cosas me han sido entregadas por mi carácter de Párroco de la localidad y bajo secreto de confesión, con orden de enviárselas a V. como así hago.

Como V. no ignora lo inviolable que es el secreto de la confesión sacramental, no conozco a la persona que me los ha dado ni a quién pertenecen los objetos que les remito.

Quedo siempre de V. affmo. Capellán en C.B.

Primitivo Sanz (Sento, Dr. Uriel 400)

El deseo de construir el relato como una representación realista de lo histórico le hace a Sento reconstruir edificios, centros urbanos, monumentos o momentos históricos, lo vuelvo a decir, representados, fijados, originalmente en fotografías, que fueron, como en el caso de la foto de Capa o en la de la figura 6, iconos de su tiempo por reconocibles por varias generaciones. Un caso concreto lo vimos con anterioridad con la foto de Capa, y ahora veremos otro aparentemente real o neutral, pero que es pura representación instantánea y subjetiva de la entrada triunfal de los vencedores nacionales en Valencia que, recordemos, fue capital de la II República española.

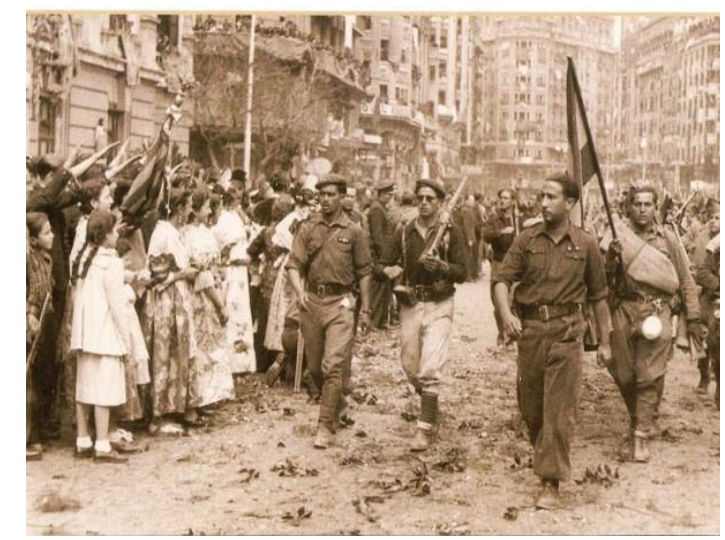

Figura 6: Entrada de los nacionales en $\mathrm{Va}$ lencia

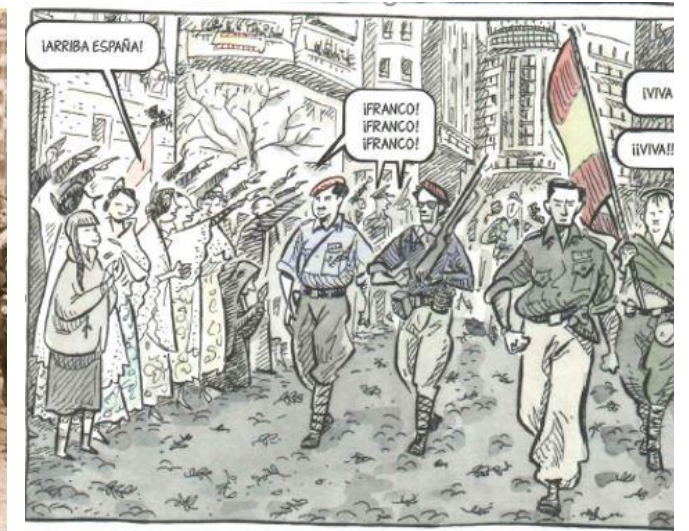

Figura 7: Entrada de los nacionales en Valencia (Sento, Dr. Uriel 385)

Evidentemente entre las narraciones No se fusila en domingo y El Doctor Uriel, y a pesar de que relatan unas historias fundamentadas en unos hechos idénticos, hay diferencias fundamentadas por las dos diferentes estrategias narrativas utilizadas — testimonial y postestimonial - y por el cambio de género.

Una de ella se observa en la importancia dada al piragüismo del doctor y que cobrará la importancia de la apertura y el cierre del texto en trilogía. Ambos motivos aparentemente parecen ser los mismos, en ambos aparece Uriel y el motivo de su vida deseada: la piragua. Pero mientras en la apertura el protagonista es un Uriel que goza de un buen día con su piragua en el río Ebro, en el cierre Uriel es un mero observador de otra piragua esta vez por el río Turia y con una sensación de haber transcurrido un siglo y de que el futuro se muestra muy incierto. 


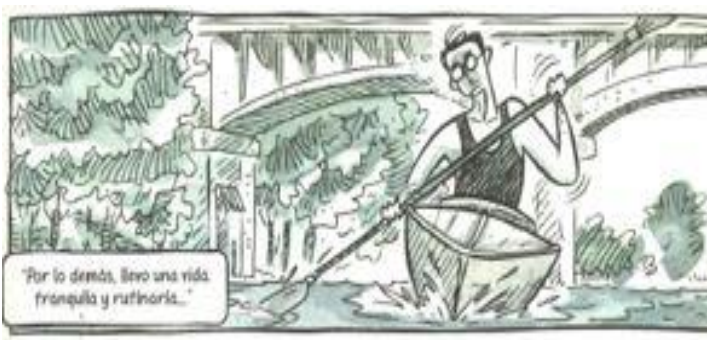

Figura 8: La piragua en el Ebro al inicio de la trilogía (Sento, Dr. Uriel 29)

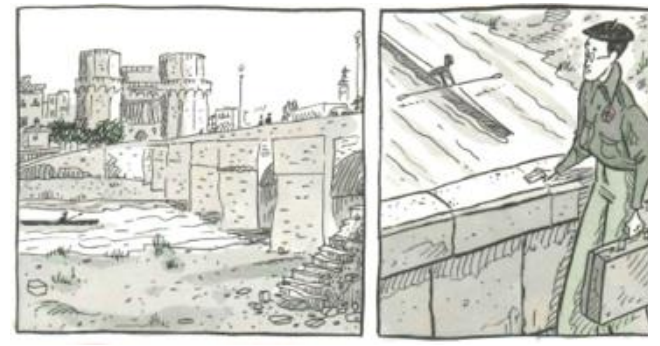

Figura 9: Otra piragua, otro piraguista al final de la trilogía (Sento, Dr. Uriel 387)

El texto dialoga constantemente con el anexo paratextual en esa especie de legitimidad documental, pero además hay todo un conjunto de paratextos ajenos a la línea temporal de la narración que le confieren una perspectiva humana, individual. Al final del relato Uriel pregunta a una monja enfermera si sabe dónde puede encontrar a su amiga Cecilia, el texto finaliza y se abre un paratexto informativo que refuerza la imagen de exilio interior u oposición, la actitud ética del resistente de Uriel: "A Pablo Uriel le fue concedida, en febrero de 1941, la medalla de sufrimiento por la patria. Nunca fue a recogerla" (Sento, Dr. Uriel 395). Y por fin con un toque de normalidad hasta climatológica un nuevo narrador que ya no es Uriel nos responde a modo de colofón narrativo a las preguntas dirigidas a la monja del hospital de la facultad de medicina de Zaragoza.

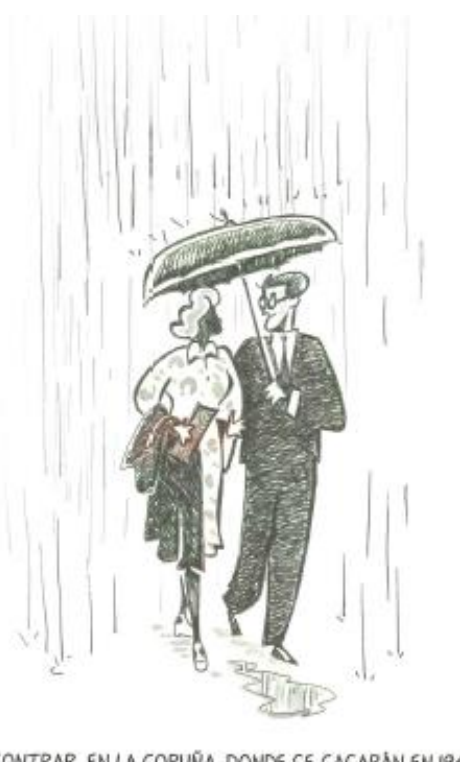

CECILIA Y PABLO SE VOLVERAN A ENCONTRAR EN LA CORUÑA, DONDE SE CASARAN EN 1944.

Figura 10: "Cecilia y Pablo se volverán a encontrar en La Coruña donde se casarán en 1944” (Sento, Dr. Uriel 396)

Por fin todo el artefacto gráfico-literario de Uriel-Sento no solamente se presenta desde su perspectiva testimonial memorialista o posmemorialista, sino que el propio Llobell elaboró también un sitio en la red con explotaciones didácticas pensadas para el aula escolar: "El Dr. Uriel en las aulas", sitio que abrió el camino a otros materiales didác- 
ticos referidos al mismo texto, como las didactizaciones de Beatriz Cuartero o de Rafael Álvarez Torregrosa, Rafael y Felipe Sigüenza Tarí, incluidas en exposiciones biobibliográficas como ejemplos de divulgación participativa de unas vidas, unos textos y su contexto histórico.

\section{A modo de conclusión}

La intencionalidad original de los textos comentados ha sido la apuntada en las estancias cervantinas mencionadas al inicio de este artículo: "parar las aguas del olvido". Los textos de Pablo Uriel, Elena Uriel y Vicent Josep Llobell Bisbal son un buen ejemplo de imbricación de las filiaciones ideológicas y genealógicas, y de las diferencias entre los textos testimoniales y los textos basados en testimonios. En otras palabras, son materiales que, didactizados, pueden ser inscritos en cursos de aprendizaje de la Guerra Civil española y de sus consecuencias en la posguerra, desde una posición democrática, pero no limitándose a ese asunto. Los textos referidos al doctor Uriel pueden ser didactizados por temas tales como: la diferencia entre memoria e historia, memoria individual y colectiva, memoria e identidad, memoria y posmemoria, memoria y trauma. Y pueden contextualizarse en ámbitos como los de las diferencias entre la narración literaria y la literario-gráfica o de la literatura y el compromiso político, democrático o meramente ético. Y todo inscrito de la construcción del relato de la memoria en sus diferentes variantes, a través de las dinámicas producidas por el mero transcurrir del tiempo. 


\section{Anexos gráficos}

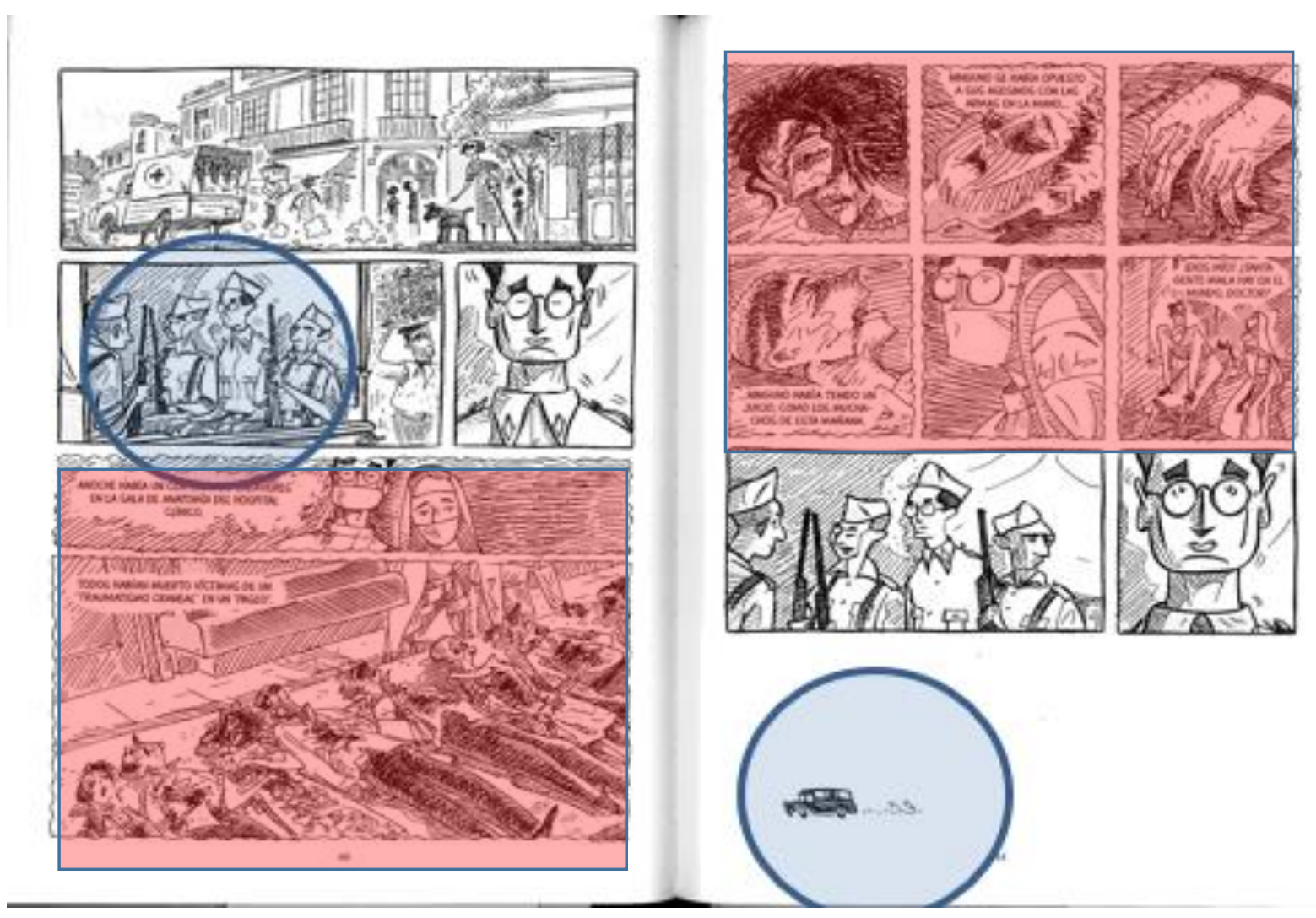

Anexo 1: En los círculos se marcan los símbolos cinéticos que indican el movimiento de las figuras. En los recuadros rojos se muestra la existencia de un relato al interior del relato principal. (Sento, Dr. Uriel 66-67) 

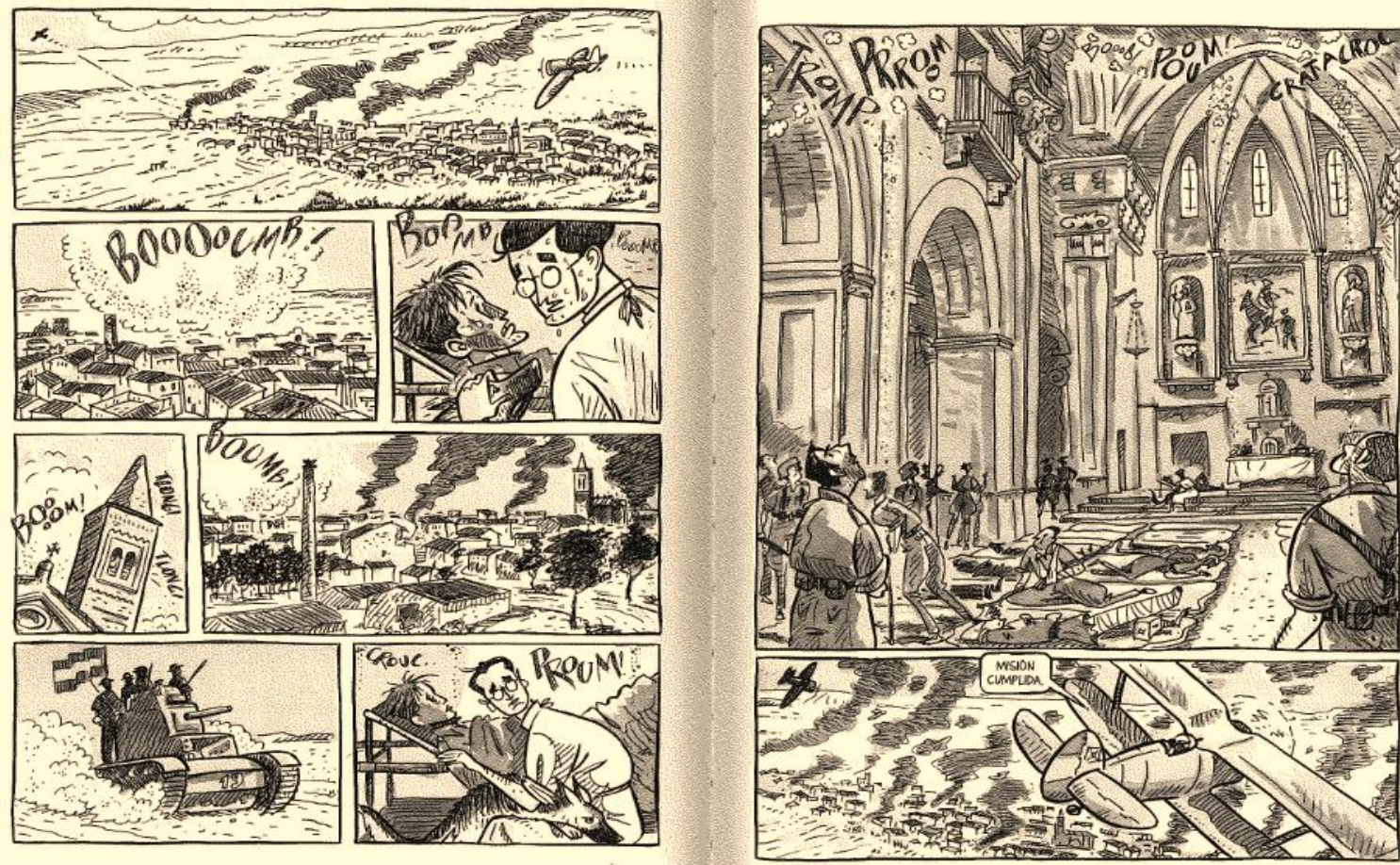

Anexo 2: En esta viñeta de la trilogía se nos describe mediante imágenes y onomatopeyas el bombardeo republicano de la iglesia de Belchite convertida en hospital por un avión Polikarpov I-15, también conocido como "Chato" y un biplano. (Sento, Dr. Uriel 230-231)

\section{Bibliografía}

\section{Obras citadas}

Arendt, Hannah. Eichmann en Jerusalén. Barcelona: De bolsillo, 2006.

Cervantes Saavedra, Miguel de. El ingenioso hidalgo Don Quijote de la Mancha. Segunda parte. Barcelona: Crítica, 1998.

Faber, Sebastiaan. "Actos afiliativos y postmemoria: Asuntos pendientes". Pasavento. Revista de Estudios Hispánicos. II.1 (2014): 137-155.

Iberley. Ley de Amnistía de 1977. Web. 30 diciembre 2020.

Hirsch, Marianne. "The Generation of Postmemory". Poetics Today 29.1 (Spring 2008): 103-128.

Izquierdo, José María. "Maquis. Guerrilla antifranquista. Un tema en la literatura actual de la memoria". Actas del XV Congreso de Romanistas escandinavos, Oslo 12-17 agosto 2002. Romansk forum 16.2 (2002): 105-116.

Izquierdo, José María. "Escribir de oídas. Última literatura de la memoria de la Guerra civil española y su posguerra". Románica Gothoburgensis 69 (2012): 385-399. 
Izquierdo, José María. "Den spanske borgerkrigen i tegneserier og grafiske romaner. Bokutstilling”. Oslo: HumSam-biblioteket, 2016. Web. 30 diciembre 2020.

Izquierdo, José María. "Un médico en la Guerra civil española: el doctor Pablo Uriel Díez". Academia.edu, 2017. Web. 30 diciembre 2020.

Izquierdo, José María. "La Guerra civil española como tema en la novela gráfica actual". BELLS 10.1 (2019): 8-17. Web. 30 diciembre 2020.

Sento [Vicent Josep Llobell Bisbal]. Sento. Web. 30 diciembre 2020.

Sento [Vicent Josep Llobell Bisbal]. Un médico novato. Madrid: Ediciones Sinsentido, $2013 / 2014$.

Sento [Vicent Josep Llobell Bisbal]. Atrapado en Belchite. Autoedición, 2015/2016.

Sento [Vicent Josep Llobell Bisbal]. Vencedor y vencido. Autoedición, 2016/2017.

Sento [Vicent Josep Llobell Bisbal]. Dr. Uriel. Bilbao: Astiberri, 2017.

Uriel, Pablo. Mi guerra civil. Valencia, Pablo Uriel Díez, 1988.

Uriel, Pablo. No se fusila en domingo. Valencia: Pre-textos, 2005.

Vázquez Montalbán, Manuel. El pianista. Barcelona: Seix Barral, 1985.

\section{Explotaciones didácticas}

Álvarez Torregrosa, Rafael y Felipe Sigüenza Tarí. “Imágenes de la memoria democrática: el cómic como recurso didáctico”. 31 octubre 2019. (Propuesta didáctica de la exposición: Imatges de la Memòria Democràtica: el còmic com a recurs didàctic. L'Eliana, 15-31.10.2019). Web. 30 diciembre 2020.

Cuartero, Beatriz. "Material para profesorado de la exposición Dr. Uriel. Viñetas de la Guerra Civil'. Ayuntamiento de Zaragoza y Centro Joaquín Roncal. XVII Salón del Cómic de Zaragoza 15.11.2018-4.1.2019. Web. http://www.zaragoza.es/cont/paginas/noticias/guadidcticadruriel.pdf]. 30 diciembre 2020.

Sento [Vicent Josep Llobell Bisbal]. "El Dr. Uriel en las aulas". 2014. Web. 30 diciembre 2020 .

\section{Nómina de algunos comics y novelas gráficas}

Ballester, Laura, Cristina Durán y Miguel A. Giner Bou. El día 3. Bilbao: Astiberri, 2019.

García, Jorge y Felipe Martínez. Cuerda de presas. Bilbao: Astiberri Ediciones, 2005.

Giardino, Vitorio. jNo pasarán! Barcelona: Norma, 2000-2008/2013.

Giménez, Carlos. 36-39 Malos Tiempos. Barcelona: Debolsillo, 2007-2011.

Giménez, Carlos. Todo Paracuellos (Ver prólogo de Juan Marsé). Barcelona: Debolsillo, 2013.

Hernández Palacios, Antonio. Eloy. Vitoria: Ikusager Ediciones, 1979.

Hernández Palacios, Antonio. 1936 Euskadi en llamas. Vitoria: Kusager Ediciones, 1981. Hernández Palacios, Antonio. Gorka gudari. Vitoria: Ikusager Ediciones, 1987

Jaraba, Fran. División azul. Castallana (Alicante): Edicions de Ponent, 2013.

Pérez Reverte, Arturo y Fernando Vicente. La Guerra civil contada a los jóvenes. Madrid: Alfaguara, 2015.

Preston, Preston y José Pablo García. La guerra civil española. Barcelona: Ediciones Debate, 2015. 
Preston, Preston y José Pablo García. La muerte de Guernica Barcelona: Ediciones Debate, 2017.

Roca, Paco. El invierno del dibujante. Bilbao: Astiberri Ediciones, 2010.

Roca, Paco. Arrugas. Bilbao: Astiberri Ediciones, 2010.

Roca, Paco. Los surcos del azar. Bilbao: Astiberri Ediciones, 2013.

Roca, Paco. La nueve. Bilbao: Astiberri Ediciones, 2014. 